\title{
Privilege AND the In-House CounSel
}

\author{
KEN B. MILLS*
}

Corporations and their employees incorrectly assume that all communications with in-house counsel will be privileged, but there are steps in-house counsel can take to minimize the disclosure of vulnerable communications.
Les entreprises et leurs employés supposent à tort que toutes les communications avec un conseiller juridique interne sont protégées par le privilège. Il existe cependant certaines mesures que le conseiller juridique interne peut prendre pour réduire la divulgation de communications vulnérables.

\section{TABLE OF CONTENTS}

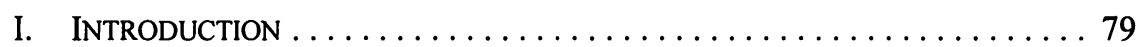

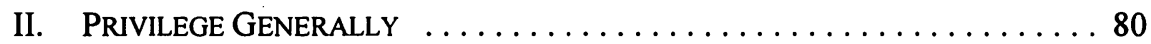

III. PRIVILEGE AND THE IN-HOUSE COUNSEL $\ldots \ldots \ldots \ldots \ldots \ldots \ldots \ldots 2$

A. THE LAW SOCIETY OF ALBERTA

AND THE IN-HOUSE COUNSEL $\ldots \ldots \ldots \ldots \ldots \ldots \ldots \ldots \ldots$

IV. Waiver of Solicitor-Client Privilege $\ldots \ldots \ldots \ldots \ldots \ldots \ldots \ldots$

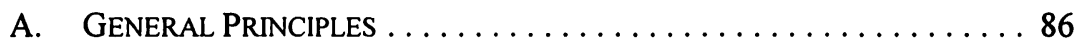

B. VOlUNTARY WAIVER $\ldots \ldots \ldots \ldots \ldots \ldots \ldots \ldots \ldots \ldots \ldots$

C. UNINTENTIONAL WAIVER $\ldots \ldots \ldots \ldots \ldots \ldots \ldots \ldots \ldots \ldots$

V. Selected CASES INVOLVING PROBlems WITH

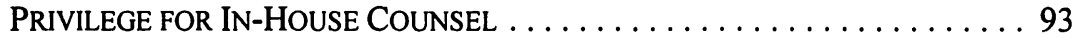

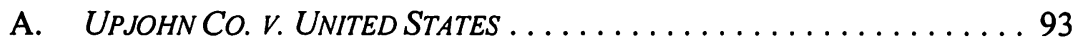

B. HUSKY OIL OPERATIONS LTD. V. MACKIMMIE MATTHEWS ....... 95

C. EXXON MOBIL V. STATE OF ALABAMA DEPARTMENT

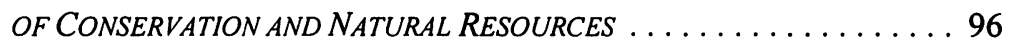

VI. WAIVer AND THe IN-House Counsel $\ldots \ldots \ldots \ldots \ldots \ldots \ldots \ldots$

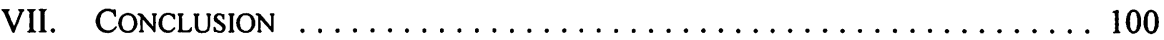

\section{INTRODUCTION}

The reason for the existence of solicitor-client privilege seems basic enough - full and frank communication must be allowed between solicitors and the clients they serve. If clients are able to receive candid advice without fear of possible reprisals due to the disclosure of information, observance of laws will be encouraged and the administration of justice will be furthered.' As such, the public interest will ultimately be served. This said, in-house counsel face few issues as perplexing and potentially perilous as the proper application of the law of solicitor-client privilege.

Blake, Cassels \& Graydon LLP, Calgary, Alberta. I would like to acknowledge the valuable contribution of Stephen Wheeler and Cory Exner, both of Blake, Cassels \& Graydon LLP, who contributed to this article.

Upjohn Co. v. United States, 449 U.S. 383 at 389 [Upjohn]. 


\section{Privilege Generally}

A useful starting point for any discussion of solicitor-client privilege as it relates to inhouse counsel involves an examination of the theory behind the privilege. Solicitor-client privilege is founded upon the premise that persons have a right to protected communication with lawyers for the purpose of soliciting and obtaining legal advice. The roots of this privilege rest within the British common law. The classic statement of privilege is described by Wigmore:

Where legal advice of any kind is sought from a professional legal advisor in his capacity as such, the communications relating to the purpose made in confidence by the client are at his instance permanently protected from disclosures by himself or by the legal advisor, except the privilege be waived. ${ }^{2}$

In $R$. v. Murray, ${ }^{3}$ the Court laid out with precision the current Canadian law on solicitor-client privilege. Citing Smith $v$. Jones, ${ }^{4}$ a 1999 decision of the Supreme Court of Canada, the Court summarized the following statements regarding solicitor-client privilege:

- The solicitor-client privilege allows the client to speak freely to his or her solicitor without fear that what is said will be divulged.

The solicitor-client privilege is the highest privilege recognized by our courts.

The privilege is that of the client.

The privilege is of fundamental importance to the administration of justice and, to the extent possible, it should be maintained.

The onus is on those who seek to set aside the privilege to justify taking such a significant step.

The privilege is no longer regarded merely as a rule of evidence which acts as a shield to prevent privileged materials from being tendered in evidence. It is a substantive rule with these features:

1. The confidentiality of communications between solicitor and client may be raised in any circumstances where such communications are likely to be disclosed without the client's consent.

2. Unless the law provides otherwise, when and to the extent that the legitimate exercise of a right would interfere with another person's right to have his communications with his lawyer kept confidential, the resulting conflict should be resolved in favour of protecting the confidentiality.

3. When the law gives someone the authority to do something which, in the circumstances of the case, might interfere with that confidentiality, the decision to do so and the choice of means of exercising that authority should be determined with a view to not interfering with it except to the extent absolutely necessary in order to achieve the ends sought by the enabling legislation.

4. Acts providing otherwise in situations under paragraph 2 and enabling legislation referred to in paragraph 3 must be interpreted restrictively.

J.H. Wigmore, Evidence in Trials at Common Law, ed. by J.T. McNaughton (Boston: Little, Brown, 1961) vol. 8 at 27.

[2000] O.J. No. 685 (Sup. Ct.) [Murray].

(1999), 132 C.C.C. (3d) 225, 169 D.L.R. (4th) 385 (S.C.C.) [Smith cited to C.C.C.] 
The rule of evidence does not in any way prevent a third party witness from introducing into evidence confidential communications made by a client to his lawyer. It is important to note, however, that before allowing such evidence to be introduced and in determining to what extent to allow it, the judge must satisfy himself, through the application of the substantive rule (No. 3), that what is being sought to be proved by the communications is important to the outcome of the case and that there is no reasonable alternative form of evidence that could be used for that purpose.

- The decision to exclude evidence that is relevant and of substantial probative value because it is protected by the solicitor-client privilege represents a policy decision.

- Notwithstanding the importance of the privilege, it is not absolute. There are exceptions:

- One exception exists when the person claiming the privilege no longer has any interest to protect and when maintaining the privilege might screen from the trier of fact information which would assist an accused.

- A second exception is found where the communications are themselves criminal (the crime/fraud exception) or they are made with a view to obtaining legal advice to facilitate the commission of a crime (the future crime/fraud exception).

- $\quad$ A third exception exists where to honour the privilege would place the safety of the public at risk. $^{5}$

Two months following its decision in Smith, the Supreme Court of Canada released a ruling dealing with the solicitor-client privilege. ${ }^{6}$ Justice Binnie, writing for the Court, made the following statements:

- The solicitor-client privilege is based on the functional needs of the administration of justice. The legal system, complicated as it is, calls for professional expertise.

- The prima facie protection for solicitor-client communications is based on the fact that the relationship and the communications between solicitor and client are essential to the effective operation of the legal system.

- The solicitor-client privilege does not attach to all advice given by a lawyer to a client. For example, the privilege does not attach to advice on purely business matters. Thus, to gain the privilege, it is not sufficient for one to say, "I went to a solicitor's office." Questions are admissible to reveal for what purpose and under what circumstances the client went to the office.

- Whether the privilege attaches in any situation depends on the nature of the relationship between the solicitor and the client, the subject matter of the advice and the circumstances in which it is sought and rendered.

- There is an exception to the principle of confidentiality of solicitor-client communications where those communications are criminal (the crime/fraud exception) or made with a view to obtaining legal advice to facilitate the commission of a crime (the future crime/fraud exception).

- The solicitor-client privilege may be waived by the client.

- A party waives the protection of the privilege when he voluntarily injects into the suit the question of his state of mind: for example, where he raises an affirmative defence that renders relevant his intent and knowledge of the law. 
- A further exception to the privilege may arise where adherence to it would have the effect of preventing the accused from making full answer and defence.

Finally, another generally accepted principle in this area is that seeking advice from a legal advisor includes consulting those who assist him professionally (for example, a law clerk) and who have had access to the communications made by the client for the purpose of obtaining legal advice. ${ }^{7}$

\section{Privilege AND The IN-House CounSEL}

More solicitors are employed as in-house counsel than ever before, a trend that is not likely to change. Within the corporation, corporate counsel may perform any of a number of distinct functions or duties. They manage and review the legal services and advice provided to the corporation by outside counsel. They supply routine legal services. They directly handle transactions. They litigate. They counsel the corporation on regulatory requirements. They create compliance programs. ${ }^{8}$ They advise employees. They advise management. They may be management. In short, there are very few roles that the modern corporate counsel are not expected to perform.

For good or for bad, in-house counsel regularly find themselves in unique and complicated positions. Much of a corporation's communication with and between outside and in-house counsel involves a mixture of legal and business advice. This mixture introduces uncertainty into the corporate environment which, in turn, may have a negative economic effect on the corporation. ${ }^{9}$ Certainly, in the increasingly competitive marketplace the value of a corporation's information can be substantial, and any preventable disclosure of sensitive information could be ruinous to a business whose existence may depend on trade secrets. Therefore, in-house counsel's ability to advise corporate management properly with respect to when communications are privileged, and how this privilege may be maintained, is fundamental to the corporation's success. That said, most corporations and their employees likely assume, incorrectly, that all communications with in-house counsel will be privileged. Since corporate counsel should not expect the corporation or its employees to understand the differences between legal and business advice as viewed by the courts, it is imperative that the solicitor herself knows the distinction. ${ }^{10}$

In the modern corporate world, there exists little difference in the treatment of in-house and outside counsel when it comes to the privileged nature of communications. For the purposes of determining solicitor-client privilege $v i s$ - $\grave{a}$-vis a corporate client, the classic statement outlining the rationale for treating in-house counsel in the same manner as external counsel in private practice was made by Denning L.J.:

Many barristers and solicitors are employed as legal advisors, full-time, by a single employer. Sometimes the employer is a great commercial concern. At other times it is a government department or a local authority. It may even be the government itself, like the Treasury solicitor and his staff. In every case these legal advisors

Supra note 3 at paras.16-17 [citations omitted].

M.C. Daly, "The Cultural, Ethical, and Legal Challenges in Lawyering for a Global Organization: The Role of the General Counsel" (1997) 46 Emory L.J. 1057 at 1062-63 [Daly].

A.C. Martin, "In-House Counsel, the Attorney-Client Privilege and Ethical Considerations in Pennsylvania" (2001) 72 Pa. Bar Assn. Q. 9 at 12 [Martin]. 
do legal work for their employer and for no one else. They are paid, not by fees for each piece of work, but by a fixed annual salary. They are, no doubt, agents or servants of the employer. For that reason, the judge thought that they were in a different position from other legal advisors who are not in private practice. I do not think this is correct. They are regarded by the law as, in every respect, in the same position as those who practice on their own account. The only difference is that they act for one client only, and not for several clients. They must uphold the same standards of honour and of etiquette. They are subject to the same duties to their client and to the court. They must respect the same confidences. They and their clients have the same privileges ... I speak, of course, of the communications in the capacity of legal advisors. It does sometimes happen that such a legal advisor does work for his employer in another capacity, perhaps of an executive nature. Their communications in that capacity would not be the subject of legal profession privilege. ${ }^{\prime \prime}$

Canadian courts have adopted a similar approach. For example, Morrison C.J.S.C. states that:

The fact that a person is by profession a solicitor and is entrusted with and performs duties which can be, and usually are performed by an official, servant or agent of the company does not render him immune from examination on discovery if he performs those duties. ${ }^{12}$

In Mutual Life Assurance of Canada v. Canada (Deputy Attorney General), ${ }^{13}$ Saunders J. states that:

The communications are privileged if they concern the employee's function as a lawyer and are not privileged if the lawyer is performing a business or other function. ${ }^{14}$

That the courts have seen fit to adopt this approach is in no small part due to the increased roles that in-house counsel play in the contemporary corporate environment. In many cases a corporation is best served by advice received by those most intimate with it. The American Corporate Counsel Association provides several reasons for this proposition. ${ }^{15} \mathrm{First}$, in-house legal advice is more easily called upon. The in-house lawyer might only be a few offices away and their telephone extension will likely be known by all who may need to call on them. The lawyer is accessible and familiar, and therefore all employees are more likely to seek the lawyer's advice and feel comfortable in doing so.

Second, in-house counsel might well be more efficient. This does not simply mean that they are less expensive, although this is usually the case, but efficient in the sense that inhouse counsel will generally serve only a single client. The counsel will know the officers of the corporation as well as its employees. They will know its business, its records, its decision-making and organizational structure, and its general modus operandi. Most importantly, they will be familiar with the recurring legal issues that the corporation faces.

Alfred Crompton Amusement Machines v. Customs and Excise Commissioners (No. 2), [1972] 2 All E.R. 353 at 376 (C.A.).

12 Canary v. Vested Estate Ltd., [1930] W.W.R. 996 at 998 (B.C. S.C.).

13 (1988), 28 C.P.C. (2d) 101 (Ont. S.C.) [Mutual Life cited to C.P.C.].

$14 \quad$ Ibid. at 104.

is Amicus curiae brief of the American Corporate Counsel Association (A.C.C.A.), filed in support of the appellant, Exxon Mobil Corporation, in the Supreme Court of Alabama, Case No. 1001053 at 18-20. These paragraphs are a summary of the A.C.C.A.'s discussion. 
As such all issues are likely not to be new issues, but rather ones that can be addressed at an intelligent and advanced stage.

Third, and directly related to the first two reasons, in-house counsel are often in a position to provide "preventative" legal advice. By reason of their accessibility and familiarity, inhouse counsel can often provide advice that will prevent an investigation or lawsuit from arising. However, efficient performance of a preventative maintenance function requires an in-depth knowledge of the corporate enterprise. Responses must be instant and consistent. ${ }^{16}$ This might well be especially true when it comes to the interpretation of contracts or other documents. For instance, the proper interpretation of a difficult clause made before a course of action is chosen will undoubtedly lead to less hardship in the future.

For these reasons in-house counsel are becoming increasingly important in the efficient functioning of modern corporations. This said, the lines will become increasingly blurred when the corporate counsel begins to wear several corporate hats. In an effort to control the costs of doing business, many corporations have expanded both the size of their legal departments and the responsibilities of those individuals who serve within them. In these situations the corporate counsel will, in addition to being the purveyor of legal advice, also be an officer or director of the corporation. In this regard, the corporate counsel will likely expand their traditional role and thereby become the purveyor of business advice. One needs to look no further than when a corporate counsel negotiates a contract on behalf of the corporation to see this inextricable intertwining of legal and business advice. As we will see, it is in these situations that privilege is either most likely to be lost or never to attach at all.

\section{A. The LaW Society Of Alberta AND THE IN-House Counsel}

Chapter 12 of the Law Society of Alberta's Code of Professional Conduct" is titled "The Lawyer in Corporate and Government Service." It begins as follows:

\section{Statement of Principle}

A lawyer in corporate or government service has a duty to act in the best interests of the corporation or the government, as they are perceived by the corporation or government, subject to limitations imposed by law or professional ethics.

Rules

1. A lawyer in corporate or government service must consider the corporation or government to be the lawyer's client.

2. A lawyer may act in a matter for another employee of a corporation or government only if the requirements Rule \#2 Chapter 6, Conflicts of Interest, are satisfied.

17 Law Society of Alberta, Code of Professional Conduct, Release 10 at c. 12, online: Law Society of Alberta <www.lawsocietyalberta.com/Info_lawyers/code/conduct.asp $>$ [Code]. 
3. If a lawyer while acting for a corporation or government receives information material to the interests of the corporation or government, the lawyer must disclose the information to an appropriate authority in the corporation or government.

4. A lawyer must not implement instructions of a corporation or government that would involve a breach of professional ethics or the commission of a crime or fraud. ${ }^{18}$

The commentary relating to Chapter 12 provides helpful advice in relation to the interpretation of the Rules. For instance, it states that "while the ethical standards that apply to lawyers, corporations and government are the same as those applying to other lawyers, the existence of an employment relationship may generate issues that do not normally arise in private practice." 19 In addition, the commentary mentions that the client of an in-house counsel is the corporation itself, and not the board of directors, shareholders, officers, employees, or another component of the corporation..$^{20}$

The Code is clear that in-house solicitors remain bound by the same ethical obligations as all lawyers. Arguably they may even have more onerous obligations in certain instances. For instance, Chapter 15 of the Code deals with lawyers and activities other than the practice of law. It reads:

\section{Statement of Principle}

Activities engaged in by a lawyer other than the practice of law must not compromise the lawyer's professional responsibilities nor bring discredit to the profession.

\section{Rules}

1. When there may be confusion as to the capacity in which a lawyer is acting, the lawyer must ensure that such capacity is made as clear as possible to anyone with whom the lawyer deals.

2. A lawyer's conduct in an activity other than the practice of law must be compatible with the best interest of the profession and justice system. ${ }^{21}$

The in-house counsel who purports to give business advice on a matter, rather than legal advice, might have an ethical obligation to disclose the capacity in which he is acting and to make sure that his corporate client understands the distinction. 


\section{Waiver of Solicitor-Client Privilege}

\section{A. General Principles}

Solicitor-client privilege can be waived.$^{22}$ Generally, the privilege which arises out of a legal relationship belongs to the client, and not to the solicitor. ${ }^{23}$ However, in addition to the right of a client to waive the privilege, it has also been established that such waiver can be made through the client's agent. ${ }^{24}$ Furthermore, there may be instances in which someone other than the client or the solicitor could waive the privilege. For instance, where a corporation elects to answer through a particular corporate employee, the answer given and any waiver made will likely bind the corporation. ${ }^{25}$

From the case law it appears that there are three main instances where solicitor-client privilege can be waived: (1) voluntarily or expressly; (2) by implication; and (3) by inadvertent disclosure. Each of these will now be discussed in turn.

\section{B. VOLUNTARY WAIVER}

Voluntary waiver of privilege occurs where the client voluntarily discloses communications with his solicitor that would otherwise have been treated as confidential. ${ }^{26}$ Traditionally, in order to establish that a privileged communication has been voluntarily waived, certain requirements had to be met: (1) the client must have known of the privilege; (2) the client must have the right to claim the privilege; (3) the client must have the clear intention to relinquish the protection of this privilege; and (4) the client must have appreciated the consequences of the result. ${ }^{27}$

Examples of voluntary waiver could include, among others, the filing of an affidavit which sets out the substance of solicitor-client communications, ${ }^{28}$ circumstances in which a solicitor

Descoteaux v. Mierzwinski, [1982] I S.C.R. 860 [Descoteaux].

J. Sopinka, S.N. Lederman \& A.W. Bryant, The Law of Evidence in Canada, 2d ed. (Toronto: Butterworths, 1999) at 756 [Sopinka], citing Geffen v. Goodman Estate, [1991] 2 S.C.R. 353.

Syncrude Canada Ltd. v. Canadian Bechtel Ltd. (1992), 10 C.P.C. (3d) 388 (Alta. C.A.).

R.D. Manes \& M.P. Silver, Solicitor-client Privilege in Canadian Law (Toronto: Butterworths, 1993) at 206 [Manes], citing Mayor of Swansea v. Quirk (1879), 5 C.P.D. 106 at 108. Manes argues at 206 that waiver may not be binding when the corporation has no choice about who is to be discovered:

The rationale for the distinction seems to be that where a corporation chooses a corporate employee who is also a solicitor as a means of dodging the answering of interrogatories, the courts will not legitimize the scheme and will hold privilege to have been waived by such appointment. However, where a particular employee required to answer happens to be the solicitor as well, there is no voluntariness to the decision, and any privilege claimed will be allowed if valid. Although the authors agree with the principle that a solicitor called as a witness can waive the client's privilege, it is no longer the law that the mere calling of the solicitor waives the privilege.

Ibid. at 189.

Sopinka, supra note 23 at 756 . Despite this, Sopinka points out that other considerations, such as fairness to the opposite party and the consistency of positions, may have overtaken these traditional factors (at 756).

Smith v. Smith, [1958] O.W.N. 135 (H.C.J.). 
swears an affidavit on behalf of a client, ${ }^{29}$ or the more obvious cases where a client voluntarily discloses or consents to disclosure of any material part of a privileged communication. $^{30}$

\section{UNintentional WAiver}

Of specific importance to this paper, and indeed to in-house counsel everywhere, is unintentional waiver of privilege, which can be further divided into two categories: implied waiver and inadvertent waiver. As solicitor-client privilege will shield protected communications, care must be taken to not implicitly waive the privilege.

\section{IMPLIED WAIVER}

Generally, waiver can be implied where the courts find that an objective consideration of the client's conduct demonstrates an intention to waive privilege. ${ }^{31}$ In $S . \& K$. Processors Ltd. v. Campbell Ave. Herring Producers Ltd. ${ }^{32}$ an application was made pursuant to which the plaintiff sought production of various documents relating to an accounting report prepared on behalf of the defendant. The requested documents included: (1) correspondence between the defendants' solicitors and the accounting firm for the purpose of preparing the accounting report; (2) notes at meetings between the accounting firm and representatives of the defendants and their solicitors; (3) working papers of representatives of the defendants; and (4) working papers of the accounting firm.

The defendant objected to the production of all of these documents, asserting that they were confidential in nature and were made only for the purpose of giving advice and preparing evidence under the direction of the defendants' solicitors. ${ }^{33}$ It was the plaintiff's submission that none of the documents in question were privileged, and if they were, that privilege had been waived by disclosure of the accounting report.

Hanna v. Hanna (1986), 53 O.R. (2d) 251 at 253-54 (S.C.). According to Manes, supra note 25 at 190 , in this circumstance the privilege will be waived "to the extent that the solicitor cannot refuse on the grounds of privilege to answer questions (regarding the facts and issues raised in the affidavit) at the cross-examination on the affidavit. Were it otherwise, the solicitor could be inserted as a deponent and render cross-examination meaningless due to privilege."

Sopinka, supra note 23 at 756 . For instance, Sopinka, at 756-57, examined various circumstances:

A client had waived the privilege which attached to letters passing between himself and his solicitor because they had been read into the record in a previous proceeding. In other cases, waiver was said to have taken place when documents over which privilege was claimed had been disclosed in proceedings in another jurisdiction or were referred to in an Affidavit of Documents and had been inspected. Similarly, if a client testified on his or her own behalf and gives evidence of a professional, confidential communication, he or she will have waived the privilege shielding all of the communications relating to the particular subject-matter. Moreover, if the privilege is waived, then production of all documents relating to the acts contained in the communication will be ordered. 
The Court dismissed the plaintiff's application for production. According to the Court, the report in question was produced pursuant to the British Columbia Evidence Act. ${ }^{34}$ Because of this, the Court concluded that the pretrial production of this report and the following loss of privilege at that stage could not said to be voluntary, being compelled by statute. As it was not voluntary, it could not constitute waiver. ${ }^{35}$ In addition, even if production of the report pursuant to the Evidence Act could have been said to constitute waiver, it was not, given the circumstances, unfair or inconsistent that the defendant who produced it retain such privilege as was left to them by the Evidence Act. ${ }^{36}$ Justice McLachlin, as she then was, described implied waiver of solicitor-client privilege as follows:

\footnotetext{
Waiver of privilege is ordinarily established where it is shown that the possessor of the privilege (1) knows of the existence of the privilege, and (2) voluntarily evinces an intention to waive that privilege. However, waiver may also occur in the absence of an intention to waive, where fairness and consistency so require. Thus waiver of privilege as to part of a communication, will be held to be waiver as to the entire communication. Similarly, where a litigant relies on legal advice as an element of his claim or defence, the privilege which would otherwise attach to that advice is lost....
}

In the cases where fairness has been held to require implied waiver, there is always some manifestation of the voluntary intention to waive the privilege at least to a limited extent. The law then says that in fairness and consistency, it must be entirely waived. ${ }^{37}$

Two relatively common methods of implicitly waiving privilege are: (1) through pleadings; and (2) by placing legal advice or knowledge in issue.

\section{a. $\quad$ Pleadings}

Simple reference to a communication in a pleading does not waive privilege. However, if the contents of a communication are sufficiently divulged or sufficient reliance is placed on the communication in the pleading, privilege will be lost. ${ }^{38}$ This principle has been summarized as follows:

Denning M.R. stated that a reference to documents in pleadings indicates an intention to rely on them and, therefore, they ought to be produced. Where privilege is contended, he left scope for amending the pleading by striking out the reference to them. Donaldson L.J. stated that a mere reference in a pleading will not waive privilege.... Further, if a document is reproduced in full, he held that privilege is waived.... Where the line is to be drawn between these two extremes was stated to be a matter of some nicety, which it was not necessary to decide in this case. Bridgeman L.J. agreed that a reference to a document's contents in a pleading does not waive privilege. However, he also stated that a party cannot rely on a pleaded privileged document without waiving the privilege. Therefore, a party must determine whether to forego privilege, or abandon reliance on the document. ${ }^{39}$

R.S.B.C. 1979 , c. 116, s. 11.

Supra note 32 at 221.

Ibid. at 221-22.

Ibid. at 220-21.

Manes, supra note 25 at 196.

Ibid. at 196, citing Buttes Gas \& Oil v. Hammer and Others (No. 3), [1980] 3 All E.R. 475 at 490 (C.A.) [Buttes Gas \& Oil]. 
It has been suggested by Manes that the approach as set out in Buttes Gas \& Oil is correct. However, they further suggest that whether or not the document is referred to in full there is only one test. In their opinion the issue of reliance is also crucial, as reliance on a document also destroys any intention of confidentiality. It is also important to note that the authors also see the disclosure of the privileged communication in a pleading to be analogous to disclosure of the communication in an Affidavit of Records. Ultimately, so long as the contents of the communication have not been disclosed, the communication will be capable of withdrawal. ${ }^{40}$

\section{b. Waiver by Placing Legal Advice or Knowledge in Issue}

If a party places the legal advice he sought or received in issue, the court may treat such conduct as implied waiver. It is considered that fairness and consistency require disclosure of the entire body of advice received by the witness. The principle applies whether the witness gives facts surrounding the received legal advice or refuses to answer any question by relying upon the fact that he or she acted upon the legal advice.

The Alberta courts appear to have adopted this view. In Ed Miller Sales \& Rentals Ltd. v. Caterpillar Tractor $\mathrm{Co} .{ }^{41}$ the plaintiff sought a declaration that the defendant had waived solicitor-client privilege with respect to legal advice obtained by the defendant regarding the formulation and implementation of a policy. The plaintiffs claimed that, by their pleadings and through the evidence led at trial, the defendants placed in issue the state of their corporate minds, thereby waiving privilege. In this regard, Berger J. described the general principle as follows: "A party may waive privilege by a pleading as well as by actually giving evidence of a privileged communication: Rogers v. Bank of Montreal.",42

However, the Court went on to further imply that whenever and however state of mind is placed in issue, solicitor-client privilege will not necessarily yield. ${ }^{43}$ In order for privilege to be waived, reliance by the disclosing party upon the legal advice that was obtained may voluntarily put into issue the question of the state of mind of the disclosing party, thereby rendering relevant the discovery of that party's reliance. ${ }^{44}$ In the words of Berger J.:

I am mindful of the pleadings, of the testimony of the witnesses to date, and of the writings received in evidence. The ... defendants rely neither on the acts and representations of the Plaintiff, nor, for any purpose, upon the legal advice received by them from time to time from their solicitors. ${ }^{45}$

In Talisman Energy Inc. v. Petro-Canada Inc. ${ }^{46}$ there was an application by the defendant for an order directing a representative of the plaintiff to answer questions put to the representative in cross-examination of an affidavit filed in support of the Plaintiff. In the affidavit, there were references to legal advice having been obtained, although it did not 
detail the content of that advice. The Court went through a discussion of the cases in which reference was made to the fact that advice had been obtained on an issue. In particular, the Court states that Berger J.'s judgment in Ed Miller cannot be interpreted as suggesting that, without more, simply referring in pleadings or evidence to the fact that legal advice was obtained constitutes a waiver. In addition, Hart J. stated that:

Under these authorities, waiver is triggered by demonstrating reliance on legal advice for the resolution of an issue, not by the mere reference to having received it. Accordingly, with respect to legal advice taken regarding the initial defence, [the Plaintiff] has not waived privilege by virtue of [the representative's] affidavit simply referring to having received that advice. ${ }^{47}$

Other cases have specifically held that where the existence or adequacy of the legal advice is not in itself a basis for the claim or the defence, the privilege is not waived by simple reference to legal advice in pleadings or disclosed documents. ${ }^{48}$

This issue was addressed in Stuart Olsen Construction Inc. v. Sawridge Plaza Corp.$^{49}$ The defendants applied for production of various documents they felt were relevant to the state of mind of the plaintiff during negotiations of several agreements entered into with the defendants and various third parties. The plaintiff refused production on the grounds of solicitor-client privilege. The defendant based its application upon several grounds: (1) that the officer produced by the plaintiff during examination for discovery waived privilege to its solicitor's documents when it put its state of mind during the negotiations and the execution of the agreements into issue; (2) that the documents were relevant to the state of mind of the plaintiff during the period of time the agreements were negotiated and executed; and (3) since the plaintiff requested payment of its legal fees in relation to the agreements, the defendants were entitled to review the solicitor's file in order to determine whether the defendants were legally obligated to pay the expenses. The court, in dismissing the defendant's application for production, stated that solicitor-client privilege is not waived by merely disclosing that a solicitor's advice was obtained, nor was it waived when the evidence shows that the client, by his words or actions, chose a course of action because of advice given to him by his counsel, and that he relied on this for resolution of an issue at trial. ${ }^{50}$

While it was true that the plaintiff raised in its pleadings reliance on certain acts and representations of the defendants, it was also clear that the plaintiff had made no claim that any legal advice had formed or was the foundation of its reliance. ${ }^{51}$ In this regard, the Court stated that:

Solicitor-client privilege is not waived by disclosing that a solicitor's advice was obtained. It is waived when the evidence shows that the client by his words or actions held a view or followed a course because of advice given to him or perhaps not given to him by his counsel and that he relied on this act or omission for resolution of an issue at trial.

Ibid. at 350 .

See e.g. Lac La Ronge Indian Band v. Canada, [1996] 10 W.W.R. 625, (1996) 147 Sask. R. 257

(Q.B.); Sabem Developments Ltd. v. Dutchmen Homes Ltd. (1976), I C.P.C. 101 (Ont. H.C.).

[1996] 2 W.W.R. 396 (Alta. Q.B.), aff'd 193 A.R. 173 (C.A.) [Stuart Olson].

Ibid. at 404.

Ibid. 
Indeed, though perhaps characterized as a "state of mind" issue it seems to me that this issue is better characterized as a simple disputed issue of fact. And an issue of fact whose resolution cannot be assisted by disclosing any advice its solicitors may have given to it. In saying this I recognize that the evidence is that the plaintiff's "state of mind" on this issue was formed by its own experience and history with the defendants and that the plaintiff has not introduced or interjected the question of legal advice in support of its position. ${ }^{52}$

As clarified in Talisman Energy, ${ }^{53}$ under these authorities waiver is triggered by demonstrating reliance on legal advice for the resolution of an issue, not by mere reference to having received it.

Another instance in which privilege may be implicitly waived is when a party, by his testimony or pleading, voluntarily raises a defence or asserts a claim which makes his knowledge of the law relevant. ${ }^{54}$ Justice Mason in Petro-Can Oil \& Gas Corp. v. Resource Service Group Ltd..$^{55}$ established that the underlying rationale for finding implied waiver in such circumstances is based on fairness. It would be unfair to permit a party who has set up a claim or defence based on privileged communications to preclude his opponent from discovering against that claim by relying upon the privilege. The facts of Petro-Can were as follows: in 1981, the defendant agreed to purchase the oil and gas assets of the Petro-Can Oil $\&$ Gas Fund, a limited partnership in which the plaintiff was the general partner. On the second day of closing, the defendant gave to the plaintiff a letter stating that the defendant refused to close the transaction, citing the failure of the plaintiff to satisfy certain conditions precedent. The plaintiffs applied to the court for an order requiring production of a solicitor's opinion received by the defendant in respect of the disputed conditions. The defendants objected to the production of the opinions on the basis of solicitor-client privilege. At issue was whether or not the legal opinions were relevant to the issues raised in the statement of defence, and if so, whether solicitor-client privilege would protect them from production.

The Court held that the legal opinions were relevant and were not protected by solicitor-client privilege. According to the court, any solicitor-client privilege which may have attached to the opinions had been waived by the defendant. ${ }^{56}$ The Court went on to state that "[i]t is well accepted that a party may [impliedly] waive solicitor-client privilege where it relies in part upon the privileged communications to either ground its claim or base it defence to a claim made against it." ${ }^{\text {}} 7$ The Court further stated that it would be unfair to permit a party who has set up a claim or defence based on privileged communications to then preclude its opponent from discovering against that claim by asserting the privilege. ${ }^{58}$ In conclusion, the Court stated that:

Ibid.

Supra note 46.

See e.g. Alberta Wheat Pool v. Estrin, [1987] 2 W.W.R. 532, (1986), 49 Alta. L.R. (2d) 176 (Q.B.);

Nowak v. Sanyshyn (1979), 9 C.P.C. 303 (Ont. H.C.).

Ibid. at 38 .

Ibid.

Ibid. 
If privilege were successfully raised, the opponent would be left with no reasonable method for exploring the validity of the claim or defence.... In the case at bar, by alleging that clauses. 9.1(v) and 9.1(xii) had not been fulfilled, the Defendant put the opinions ... referred to in those clauses in issue. In other words, the Defendant is relying in part on communications that might be privileged to base its defence that clauses $9.1(\mathrm{v})$ and 9.1(xii) had not been fulfilled. Consequently, the Defendant must be taken to have waived any privilege attaching to the ... opinions. To hold otherwise would in effect amount to providing the Defendant with an unfair advantage in this litigation which the Plaintiffs would quite likely be unable to overcome. ${ }^{59}$

However, the privilege will not be waived where it is a person who seeks the information that has raised the question of reliance. ${ }^{60}$

\title{
2. INADVERTENT Disclosure OF PRIVILEged COMMUNICATIONS
}

Occasionally, the disclosure by the client or the solicitor is completely inadvertent without any intention to waive, deliberate or implied. Indeed, there is authority for the proposition that mere inadvertence can lead to an order for disclosure. ${ }^{61}$ However, this view does not seem to be upheld by all. According to Sopinka J.:

\begin{abstract}
Where the disclosure of privileged information is found to have been inadvertent, recent Canadian cases have chosen not to adhere to the principle in Calcraft v. Guest, holding that mere physical loss of custody of a privileged document, does not automatically end the privilege. With Rules of court now providing for liberal production of documents, the exchange of large quantities of documents between counsel is routine and accidental disclosure of privileged documents is bound to occur. A judge should have a discretion to determine whether in the circumstances the privilege has been waived. Factors to be taken into account should include whether the error is excusable, whether an immediate attempt has been made to retrieve the information, and whether preservation of the privilege in the circumstances will cause unfairness to the opponent. ${ }^{62}$
\end{abstract}

A good illustration of the more modern approach is found in Royal Bank of Canada v. Lee. ${ }^{63}$ Here, a court-appointed receiver obtained an alleged confession from a principal shareholder relating to doctored inventory records. He then met with an official from the bank and the bank's lawyer and as a result he wrote a lengthy opinion letter to the lawyer with a copy to the bank. Both the receiver and the lawyer neglected to remove a copy of the letter when the receiver's records were produced to the opposite party. In determining whether privilege still attached to the document, the Alberta Court of Appeal acknowledged that older Canadian and English authorities had found that the privilege might be lost without intentional waiver ${ }^{64}$ To support this position, the Court cited Descoteaux ${ }^{65}$ and summarized the modern Canadian law as follows:

\section{Ibid.}

Lloyd's Bank of Canada v. Canada Life Assurance Co. (1991), 47 C.P.C. (2d) 157 (Ont. Gen. Div.). See e.g. Calcraft v. Guest, [1898] 1 Q.B. 159 (C.A.) [Calcraft], as cited by E.A. Dolden, "Waiver of Privilege: The Triumph of Candour Over Confidentiality" (1990) 36 C.P.C. (2d) 56 at 85. In Calcraft, privileged documents were not voluntarily relinquished. The Court held that the documents remained privileged, but that the defendant was not precluded on the ground of privilege from giving secondary evidence of their contents.

Sopinka, supra note 23 at 767 .

(1992), 127 A.R. 236 (C.A.) [Royal Bank].

Ibid. at 240.

Supra note 22. 
Therefore, older cases saying that privilege is lost when a document is dropped on the street, or when a nonparty steals it, seem very doubtful in Canada today. The recent English cases cited by both parties draw very fine distinctions as to when the equitable protection for confidences will prevail over a loss of privilege in that way. Those English cases conflict. But as Canada has abolished the old rules on loss of privilege, we need not draw those distinctions. There is no such conflict in Canada, because mere physical loss of custody does not end privilege automatically. To put it another way, privilege and confidentiality have merged in some areas of Canada, but appear distinct in England. ${ }^{66}$

The Court held that there was no loss of privilege in this case because the disclosure was entirely accidental. Further, it was established that the privilege belonged to the client (the bank), who was the only party who could waive it. Accordingly, the privilege was upheld.

Ultimately, the courts will generally favour upholding the privilege over production of the documents. It has been determined that any doubt about the client's intention or about the extent of waiver should be resolved in favour of upholding privilege. As previously mentioned, this is supported by the Supreme Court of Canada in Descoteaux. ${ }^{67}$

\section{Selected Cases Involving Problems with Privilege FOR IN-House COUNSEL}

\section{A. UPJOHN CO. v. UNITED STATES ${ }^{68}$}

In the United States, the Federal Courts have adopted a similar approach to the Canadian model regarding privileged communications made by in-house counsel. Upjohn was an American corporation that manufactured pharmaceuticals internationally. In 1976, following an audit conducted by independent accountants, it was discovered that a foreign subsidiary of Upjohn had paid several foreign governments to secure government contracts. As part of an internal investigation into "questionable payments," both the general and independent counsel of Upjohn sent a questionnaire to all foreign and general area managers, which sought all information concerning any payments made to any employee or official of a foreign government. Responses to this questionnaire were to be sent directly to the general counsel.

Subsequent to this internal investigation, the Internal Revenue Service, in investigating any tax consequences of the payments, demanded production of the questionnaires as well as any notes pertaining to meetings between corporate and outside counsel with Upjohn employees. Upjohn refused this request, claiming all communications were protected by solicitor-client privilege.

The Sixth Circuit Court of Appeals adopted the so-called "control group" test, whereby only communications from and between employees who are in position to control or take a substantial part in any decisions about corporate actions that could be made upon the advice 
of a corporate solicitor will be protected by privilege ${ }^{69}$ This approach is premised on the idea that such employees personify the corporation when they speak on its behalf. ${ }^{70}$ In the words of the Court, "communications ... made by officers and agents not responsible for directing Upjohn's actions in response to legal advice ... were not the client's."71

The Supreme Court of the United States carefully considered the policy considerations behind solicitor-client privilege. Specifically, the Court held that the lower court's adoption of the control group test "overlooks the fact that the privilege exists to protect not only the giving of professional advice to those who can act on it but also the giving of information to the lawyer to enable him to give sound and informed advice," "72 and "frustrates the very purpose of the privilege by discouraging the communication of relevant information by employees of the client to attorneys seeking to render legal advice to the client corporation." ${ }^{73}$ Furthermore, the Court indicated that the control group test excluded those employees most likely to execute the legal advice of corporate counsel. ${ }^{74}$ The resulting exclusion of those employees diminishes the effectiveness of corporate attorneys. ${ }^{75}$ Moreover, the Court believed that the control group test prevented the use of corporate counsel to ensure compliance with the law. ${ }^{76}$ Finally, the Court noted the test as applied by the lower courts resulted in unpredictability as to what communications deserve protections. ${ }^{77}$

Although Upjohn remains the federal law in the United States in relation to privilege, many states continue to adopt the control group test that was specifically rejected by the Supreme Court in Upjohn. In Canada, however, the control group test seems to have been clearly rejected. ${ }^{78}$ When examining the possible outcomes of an application of the control group test, this seems to be the more logical approach, as the control group test could effectively sterilize the effectiveness of corporate counsel. For instance, notes of interviews with or advice given to non-control group employees could be subject to production and both solicitors and non-control group employees could be required to testify about the conversations made between them. In addition, non-control group employees might be deprived of the first-hand advice of the corporate counsel with which they are expected to comply. Practically speaking, these limitations on corporate counsel and the fears that communications may become producible may discourage a fault-finding examination within the corporation or prevent adequate consideration of all legal alternatives.

Ibid. at 391 .

B.E. Hamilton, "Conflict, Disparity, and Indecision: The Unsettled Corporate Attorney-Client Privilege" (1997) Ann. Surv. Amer. L. 629 at 631, citing Philadelphia v. Westinghouse, 210 F. Supp. 483 (E.D. Pa. 1962).

Supra note 1 at 388.

Ibid. at 390.

Ibid. at 392 .

Ibid.

Ibid.

Ibid.

Ibid. at 393.

Mutual Life Assurance Co. of Canada v. Canada (Deputy Attorney General) (1988), 28 C.P.C. (2d) 101 (Ont. H.C.J.). 


\section{B. HUSKY OIL OPERATIONS LTD. V. MACKIMMIE MATTHEWS}

This was an action involving a claim for solicitor's negligence. Husky Oil Operations Ltd. (Husky) claimed that MacKimmie Matthews (MacKimmie), its former solicitor, had negligently drafted a renewal clause in an oil and gas contract. In a separate action, the renewal clause had been found to be void as it offended the rule against perpetuities. MacKimmie made this application to compel production of documents relating to the opinion of Husky's in-house counsel about the clause in issue. Husky objected to the production, stating that there was no valid reason in this case to disregard solicitor-client privilege. The defendants applied for production of three categories of documents and one specific document, namely:

(a) Communications between the plaintiffs and their solicitors giving legal opinions regarding the renewal clause;

(b) Solicitors' opinions which the defendants alleged were summarized in other documents which had already been produced;

(c) "Without prejudice" communications between the plaintiffs and PanCanadian in the prior action regarding the validity of the renewal clause; and

(d) A document prepared by a lawyer employed as a landman in the plaintiff's Land Department which contained advice on legal issues.

The defendant's application was allowed in part. The document authored by the landman was ordered produced, but all other communications and opinions were protected by solicitor-client privilege. Because the landman was not employed as in-house counsel, Husky could not claim solicitor-client privilege over any documents that she authored.

In coming to its conclusions, the Court made several important statements regarding this privilege:

- The law permits intrusion into solicitor-client privilege if a party has raised a defence or asserts a claim which puts its own state of mind into issue $;^{80}$ however, this exception will not automatically apply in cases where a party's state of mind has been put in issue by the opposing party. ${ }^{81}$

- Solicitor-client privilege is a right which must be zealously guarded. ${ }^{82}$

- The fact that a document which was produced provides information about options (which may have been distilled from legal opinions), but does not mention any information about the legal opinion itself, does not represent a waiver of privilege over those opinions. ${ }^{83}$

(1999), 241 A.R. 115 (Q.B.) [Husky].

Ibid. at 117, citing PetroCan Oil \& Gas Corp. v. Resource Service Group Ltd. (1988), 90 A.R. 220 (Q.B.).

Ibid., citing Ed Miller Sales and Rentals Ltd. v. Caterpillar Tractor Co. (1992), 3 Alta. L.R. (3d) 210 at 214 (Q.B.).

Ibid. at 118 .

Ibid. at 118-19. 
- It is incumbent on the Court to protect the sanctity of "without prejudice" communications. If the categories within which privilege can be lifted are expanded, parties may be reluctant to engage in settlement negotiations. ${ }^{84}$

- Documents prepared by a lawyer who was not employed as a lawyer per se (even though they arguably contain legal advice) cannot be claimed as solicitor-client privilege. ${ }^{85}$

\section{EXXON MOBIL V. STATE OF ALABAMA DEPARTMENT OF CONSERVATION AND NATURAL RESOURCES ${ }^{86}$}

One of the most perplexing recent findings by the American courts is the ruling in Exxon Mobil v. State of Alabama Department of Conversation and Natural Resources. The facts are as follows: in 1993, upon a request for a legal opinion, Charles Broome, one of Exxon's in-house lawyers, wrote a three-page letter (the Broome Letter) to the Exxon Project Manager for Mobil Bay. At issue was the interpretation of a royalty provision contained in Exxon's lease agreement with the State of Alabama. Based on his interpretation, Broome recognized that the lease provisions were unusual and that there were no Alabama cases directly on point. Broome concluded by advising Exxon that if his interpretation of the lease was not upheld, Exxon would be exposed to a 12 percent interest penalty for underpayment of royalties. In addition, he advised his client that his interpretation of a particular clause in the lease had "some support in the case law," but added candidly that "the likelihood of prevailing in court on this interpretation [was] less than 50\%." On other interpretation issues, Broome concluded that the lease was straightforward. Based on Broome's opinions, Exxon interpreted the leases in a manner that was certainly commercially favourable to them but, in their opinion, still entirely reasonable. ${ }^{87}$

In 1995, the State of Alabama hired an outside auditor to audit Exxon's royalty payments. In this audit, all of the disputed lease interpretation issues were directly responsible for a claim of $\$ 132.1$ million. In 1997 and 1998, Exxon met with the state's Department of Conservation and Natural Resources representatives in an attempt to settle the outstanding audit issues. After these settlement talks failed, Exxon itself filed the disputed declaratory judgment action.

At trial, an Alabama jury awarded the state compensatory damages in the amount of $\$ 87.7$ million. In addition, the jury awarded a further $\$ 3.42$ billion for fraudulent underpayment of royalties under the leases. During the course of the trial, the state contended, and the jury believed, that the Broome Letter was properly admitted into evidence. The state argued that the law of privilege reluctantly limits the body of evidence that can be made available to the jury. Because privilege denigrates the search for truth, it must be construed narrowly ${ }^{88}$ The

Ibid. at 120

Ibid.

CV-99-2368 (Circuit Court of Montgomery County) (unreported) [Exxon].

Brief of the Appellant, Exxon Mobil Corporation, in the Supreme Court of Alabama, Case No. 1001053 at $15-24$. 
state further contended that even if the Broome Letter was originally privileged, that privilege was waived when it was released to individuals who are not representatives of Exxon. According to the state there were thirteen known recipients of the Broome Letter, only three of whom could legitimately be characterized as clients. In fact, the state contended that Broome himself could not even identify four of the individuals who received the letter. ${ }^{89}$ Exxon took the position that the Broome Letter was only distributed to those individuals in a position of confidentiality within the corporation.

Exxon contends in its appeal that there is no mystery about why the jury reached the conclusion it did. It was angered by the state's distortion of materials that should have been protected by solicitor-client privilege, but were rather ordered produced and allowed as evidence. ${ }^{90}$ Broome's analysis was indeed favourable to his client, but not unreasonably so. Exxon states that Broome's approach was consistent with his role as in-house counsel: he determined whether or not it was possible to interpret the revisions in a manner favourable to his client's interest, and then advised his client as to whether or not such an interpretation would likely prevail..$^{11}$ It is Exxon's position that, when Broome said "my position may not prevail in court," the jury took that to mean that Broome believed that he knew his position was wrong. Exxon believes that this merely meant that Broome had a healthy respect for the risks and possible outcomes of litigation. ${ }^{92}$

The Exxon case should serve as a warning to both corporations and their in-house counsel. ${ }^{93}$ It has, at least at the lower court level, been interpreted prejudicially against the company retaining privilege. Intention to keep communications confidential, without more, may not be sufficient.

\section{WAIVER AND THE IN-HOUSE COUNSEL}

There is no doubt that there exists some ambiguity as to the proper application of the solicitor-client privilege doctrine, especially as it relates to in-house counsel. Given this, as a practical guide, corporations and in-house counsel should attempt to structure their legal affairs in a manner that alleviates, to the greatest extent possible, the uncertainty surrounding the privilege.

To maintain the solicitor-client privilege, the communications must begin and remain confidential and should always relate to needed legal, rather than business, advice from the solicitor. ${ }^{94}$ There are two general grounds for denying solicitor-client privilege to a corporation: (1) confidentiality is absent (either due to a waiver of the privilege that would have normally protected the communication or due to a general lack of secrecy within the

Ibid. at 118 .

Ibid. at 119 .

The appeal of the lower court's ruling was heard on 25 April 2002. However, at the time of writing of this paper, the appellate court's opinion had not yet been released. 
corporation); and (2) the communications have a business, and not legal, character. ${ }^{95}$ To ensure that confidential communications retain their character, certain steps should be taken.

First, corporations should label all written materials regarding legal communications between employees and in-house counsel as "privileged" or "confidential" and should generally keep separately labelled files ${ }^{96}$ The reason for this is twofold. First, adhering to this practice will provide some evidence (although it will be in no way determinative) to a court that the communications were intended to remain privileged or confidential. Second, even if the label carries no weight for a court's determination of the character of the communication, it will surely serve to restrict access to the contents of the document within the corporation. If fewer people see a document that contains employee communications with in-house counsel, the risk that the corporation will unintentionally waive the privilege will be minimized. ${ }^{97}$ However, it is important to note that labelling every communication with inhouse counsel as privileged will have the likely effect of causing the label to lose its effect and thereby be ignored. ${ }^{98}$ As such, corporations should not be quick to simply "rubberstamp" every corporate document as confidential if there is no bona fide legal discussion involved.

Second, corporations must only seek advice from in-house counsel that is legal in nature, and not purely related to the business of the corporation. As mentioned, privilege will attach to the former communications, but not the latter. The communications must concern the legal ramifications of some corporate decision or question. Where a solicitor requests information from an employee, it must be used to prepare legal advice. If the information is sought for an ancillary purpose, such as the preparation of a financial report, then it will not be privileged, even though it was prepared by the solicitor in the course of her duties as in-house counsel $1{ }^{99}$ In-house counsel should avoid handling matters that are generally considered to be in the domain of business executives, as a court may disfavour the protection of communications that could have been done by a non-lawyer. ${ }^{100}$ Furthermore, in-house counsel should communicate legal and business advice in separate documents whenever possible, and they should inform the reader as to why they are doing so. ${ }^{101}$

Third, corporations should never use in-house counsel as a mere conduit for corporate information. Courts will likely be suspicious of these actions and may therefore be unwilling to accommodate a claim of privilege if it appears that this filtering of information was an attempt to silence the communications. ${ }^{102}$ There must always be a legitimate reason for claiming the privilege.

Ibid.

Ibid.

A. Stevens, "An Analysis of the Troubling Issues Surrounding In-House Counsel and the Attorney-Client Privilege" (1999) 23 Hamline L. Rev. 289 at 320.

Hamilton, supra note 70 at 657-58.

Supra note 98 at 320.

Ibid. at 320-21.

Ibid. 
Finally, in-house counsel should always discuss with the business representatives of the corporation what topics will be discussed at meetings, before the actual communications take place. If this is done, in-house counsel will be able to warn the business representatives that some of the anticipated communications will likely not be protected. ${ }^{103}$ Further to this, detailed records with accurate descriptions should be maintained regarding the contents of the meetings that were made with in-house counsel. This will allow a court to determine which of the communications, if any, involved the provision of legal services and should therefore be protected. ${ }^{104}$

Further suggestions have been made to assist corporate counsel in ensuring that all privileged communications remain so. ${ }^{105}$ Some of these are duplications of those previously mentioned, but their importance cannot be understated.

- The communication needs to be with a client or prospective client. There is generally little argument about whether in-house counsel's employer is a client. There should be no doubt that in-house counsel's client is the corporation or business entity, not individual executives in their individual capacity. Communication between in-house counsel and other corporate employees is also privileged as long as the communication is necessary to provide legal advice to the corporation.

- The communication must be with a lawyer who is a member of a provincial bar, or the lawyer's subordinate.

- The lawyer must be acting in a capacity as lawyer. The lawyer cannot be acting in a business capacity at the time of the communication. Where lawyers serve in positions involving legal and management duties in a corporation, the lawyer needs to ensure that legal analysis is not commingled with management duties.

- The communication must be for the purpose of obtaining legal advice and counsel, not business advice. The in-house lawyer could, for example, incorporate phrases such as, "You inquired whether there is any legal or regulatory restraint on" or "Under the facts as you presented them, the law would allow" in his communication to demonstrate a clear intent to provide legal advice.

- The communication cannot be made in the presence of strangers.

- The communication cannot be for the purpose of committing a crime or tort.

- The privilege must have been claimed. In-house counsel can and should label documents "Solicitor-client Privilege" or "Privileged and Confidential" to make it obvious that the privilege was claimed. To limit the risk of inadvertent disclosure by the client, the solicitor should stress that the client should not discuss or disclose the confidential material without first consulting the solicitor.

- The privilege must not have been waived. In-house counsel needs to ensure that discussions concerning sensitive matters do not include individuals outside of the corporation and that documents are distributed to only those individuals who have a need for the information. 


\section{CONCLUSION}

In-house counsel must continually consider the risk of waiver in all situations. Although it is impossible to guarantee the confidentiality of all corporate information, the careful forethought of an astute in-house counsel is the best method to guard against unintentional and unnecessary disclosure of sensitive corporate communications. As the number of inhouse counsel continue to increase in the years ahead, the confidentiality of their communications will become an even greater issue.

In order to provide the comprehensive advice corporations need, an in-house solicitor must have the benefit of the same open and frank discussions with corporate employees that any lawyer needs from her client in order to provide meaningful legal advice. Even though there exists no straightforward test to ensure the benefit of the protection afforded by the solicitor-client privilege, there are steps that in-house counsel can take to minimize the likelihood that a corporation will be forced to disclose vulnerable communications. The challenge for in-house counsel is to take a proactive role in preserving the privilege from the first communication and to keep legal and non-legal communications separate. If these preventative steps are taken, corporations can expect their confidences to remain private. 